\title{
BERLIM: UMA NOVA FRONTEIRA
}

\author{
Thiago Tadeu Caetano ${ }^{1}$
}

A ideia de fotografar e vivenciar refugiados surgiu em 2015, por meio de um projeto acadêmico cuja temática era "fronteiras". Como o tema dos refugiados estava muito em evidência no ano de 2015, iniciei o trabalho abordando essas questões na cidade de São Paulo.

Primeiramente, com o objetivo de descobrir onde encontrar os refugiados na cidade, para então me aproximar das suas realidades, histórias e contextos, entrei em contato com algumas ONGs. Por meio desse contato, constatei que em São Paulo, a maioria dos refugiados são africanos e não os Sírios, que estão quase que diariamente presentes na mídia. Outro fator que me chamou a atenção, é que a maior parte dos refugiados sírios que chegam ao Brasil possuem auxilio de pessoas que já vivem aqui e que tem mais facilidade para conseguirem se estruturar melhor que os africanos

Estive em alguns eventos organizados por ONGs ou pelos próprios refugiados, onde os mesmos procuram divulgar as suas culturas e também levantar algum dinheiro fazendo comidas típicas, oficinas de beleza, dança e vendendo as suas artes. Percebe que os refugiados estabeleceram uma rede de auxilio intensa. Eles se ajudam e colaboram uns com os outros nos seus projetos, e várias ONGs se dispõem a ajudar.

Também constatei como é desigual o tratamento dado pela população aos refugiados, que claramente os diferencia. Os refugiados Sírios, com a grande cobertura da mídia, e, penso eu, também por se tratar de uma questão que se passa na Europa, tiveram muito mais apoio da sociedade paulistana, já os africanos, são constantemente marginalizados e excluídos da sociedade.

Após essa experiência, a minha vontade de continuar trabalhando com o assunto aumentou, tanto que no projeto proposto pela universidade no segundo semestre de 2016, cujo tema era "memórias", segui abordando os refugiados.

No mês de setembro de 2016 tive a oportunidade de fazer uma viagem à cidade de Berlim na Alemanha, por 10 dias. A Alemanha é o local perfeito para se aproximar dessas pessoas, já que esse é o país destino da maioria dos refugiados Sírios. É esse relato que vocês lerão a seguir.

Como o trabalho da faculdade abordava as "memorias" através de uma narrativa fotográfica, minha ideia inicial era visitar os campos de refugiados em Berlim e tentar me aproximar de alguns deles para então retratar as suas histórias desde a saída de seu país

\footnotetext{
${ }^{1}$ Thiago Tadeu Caetano é estudante do curso de bacharelado em fotografia no Senac São Paulo. Contato: thitcaetano@gmail.com.
} 
de origem até o presente momento. Minha ideia era tentar retratá-los com objetos que trouxeram consigo, que remetessem ao seu país de origem.

Como estudante, essa foi minha primeira experiência de campo internacional, por isso comecei a busca por informações aqui em São Paulo e também fazendo contato com amigos residentes em Berlim. Em São Paulo, consegui alguns contatos de pessoas que trabalham diretamente com refugiados em Berlim.Após esse contato, percebi que o local onde seria mais apropriado para fazer esse trabalho seria no aeroporto desativado de Tempelhof, local onde foi criado um dos maiores campos de refugiados na cidade. 0 aeroporto foi desativado em agosto de 2008, a pista de pouso e decolagem hoje servem de parque aberto ao público com várias opções de lazer. Com o grande número de refugiados na cidade e a chegada das baixas temperaturas, a câmara de Berlim decidiu, apesar da resistência por parte da população, usar o antigo aeroporto para receber os refugiados.

Ao chegar em Tempelhof, na entrada principal de acesso ao campo, encontrei alguns refugiados do lado de fora, crianças brincando e pessoas entrando e saindo, tanto refugiados como moradores da cidade, na sua maioria jovens que fazem trabalhos voluntários dando aulas de alemão e recreações adolescentes e crianças. Tive a sensação que parte da população alemã, principalmente os jovens tem uma "obrigação histórica" com a humanidade, e muitos querem ajudar os refugiados de diversas maneiras, quiçá essa seja uma oportunidade de se redimir em relação os acontecimentos do passado.

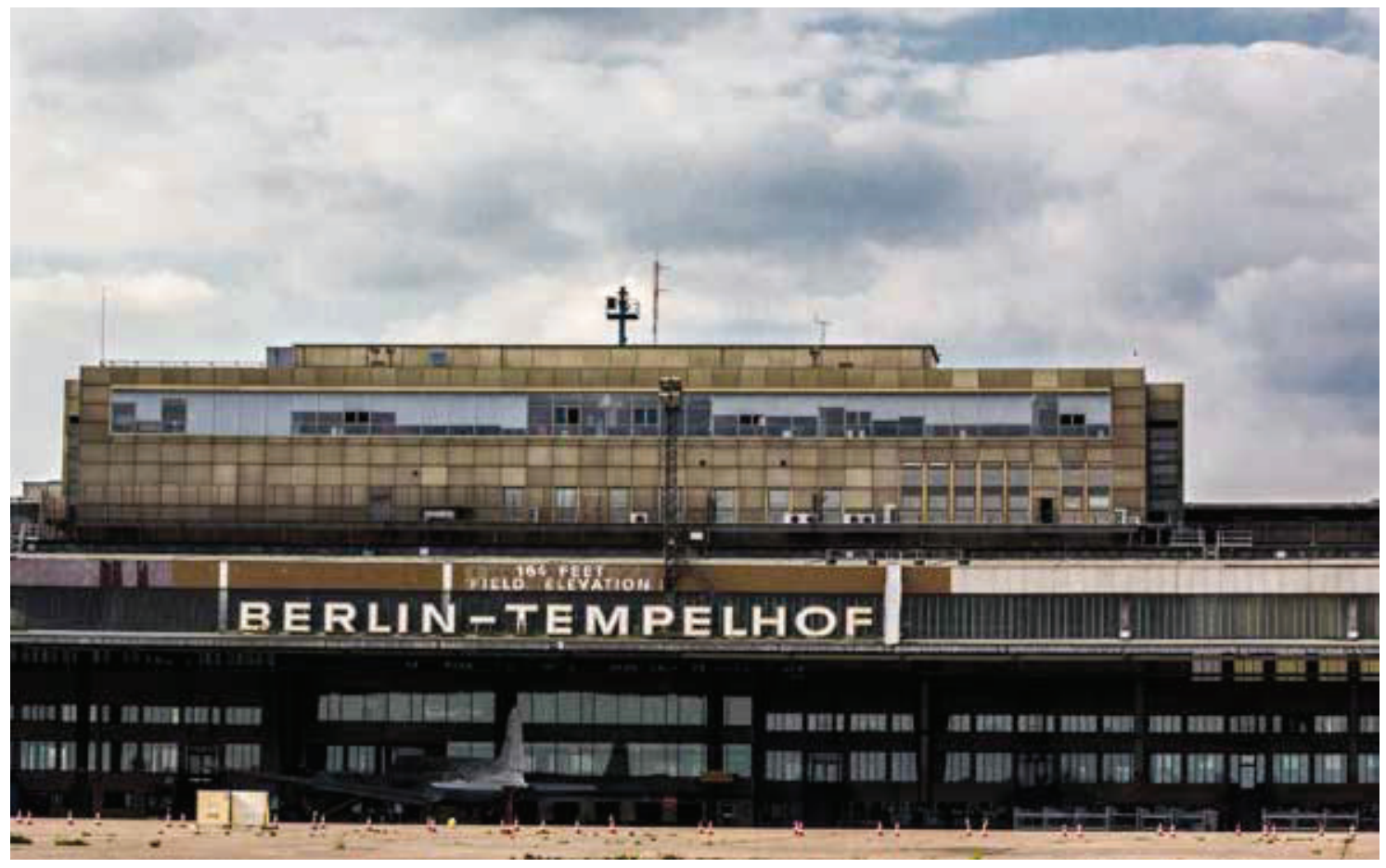

Foi o meu primeiro contato com os refugiados e logo vi que não seria tão fácil. Por causa de uma relação pessoal com a Servia, conheci o fotógrafo Marko Djurica que trabalha 
com refugiados e fez a famosa foto de uma repórter chutando um pai refugiado com seu filho, na fronteira da Servia com a Hungria. Marko esteve em locais críticos durante o percurso dos Refugiados em direção a Alemanha e em uma entrevista vi que ele sempre mostrou aos refugiados a intenção de ajudá-los e com isso conseguia se aproximar para fotografá-los, eu me inspirei no trabalho dele para realizar o meu.

Na portaria do Tempelhof, apesar da entrada e saída livre, tinha um "ar" de presídio, com seguranças, portaria de identificação e revista. Conversei com um dos seguranças, falei a intenção do meu trabalho e questionei a quem deveria pedir permissão para fotografar o lugar. 0 segurança me deu o telefone de uma pessoa que, pelo que entendi, seria a diretora do local. Continuei andando pela região da entrada do campo e pela pista onde funciona o parque, apesar de ter recebido alguns sorrisos dos refugiados que vi por ali, não tive sucesso com a abordagem para um possível "bate papo" e fotos. A principal barreira foi o idioma, todos que abordei não falavam inglês.

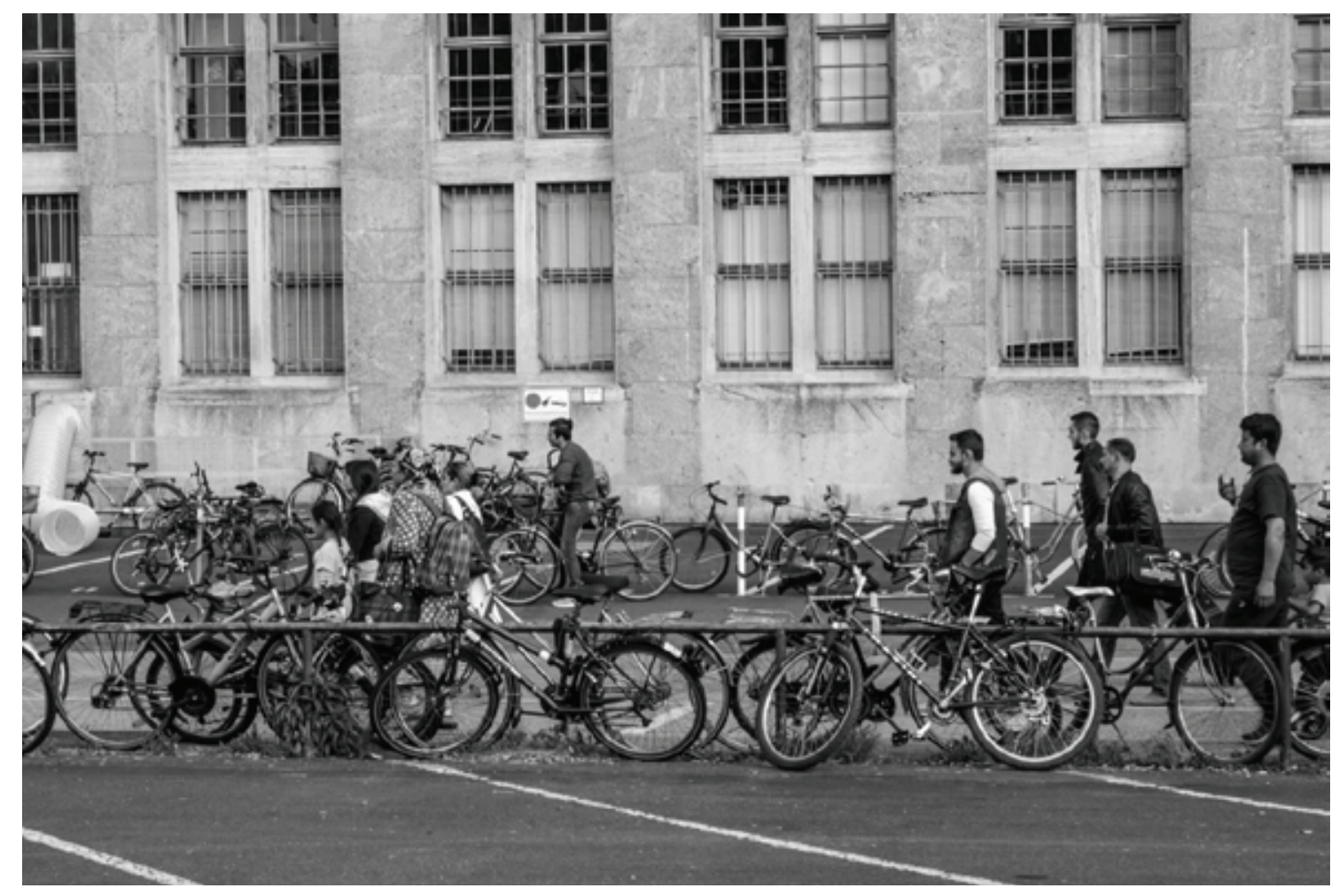

Voltei para casa e pedi para minha amiga alemã entrar em contato por meio do telefone que consegui do segurança. Minha amiga entrou em contato e explicou para a possível diretora do campo a intenção do meu trabalho e a mesma disse que não seria possível entrar no local para tirar fotos, pois se tratava de um local privado, mas que eu poderia tentar ir a um local ali perto, onde diariamente era organizado um café para os refugiados. Ela explicou que nesse café eu poderia interagir com os refugiados e poderia fazer fotos do lado de fora do antigo aeroporto. 
relato de campo

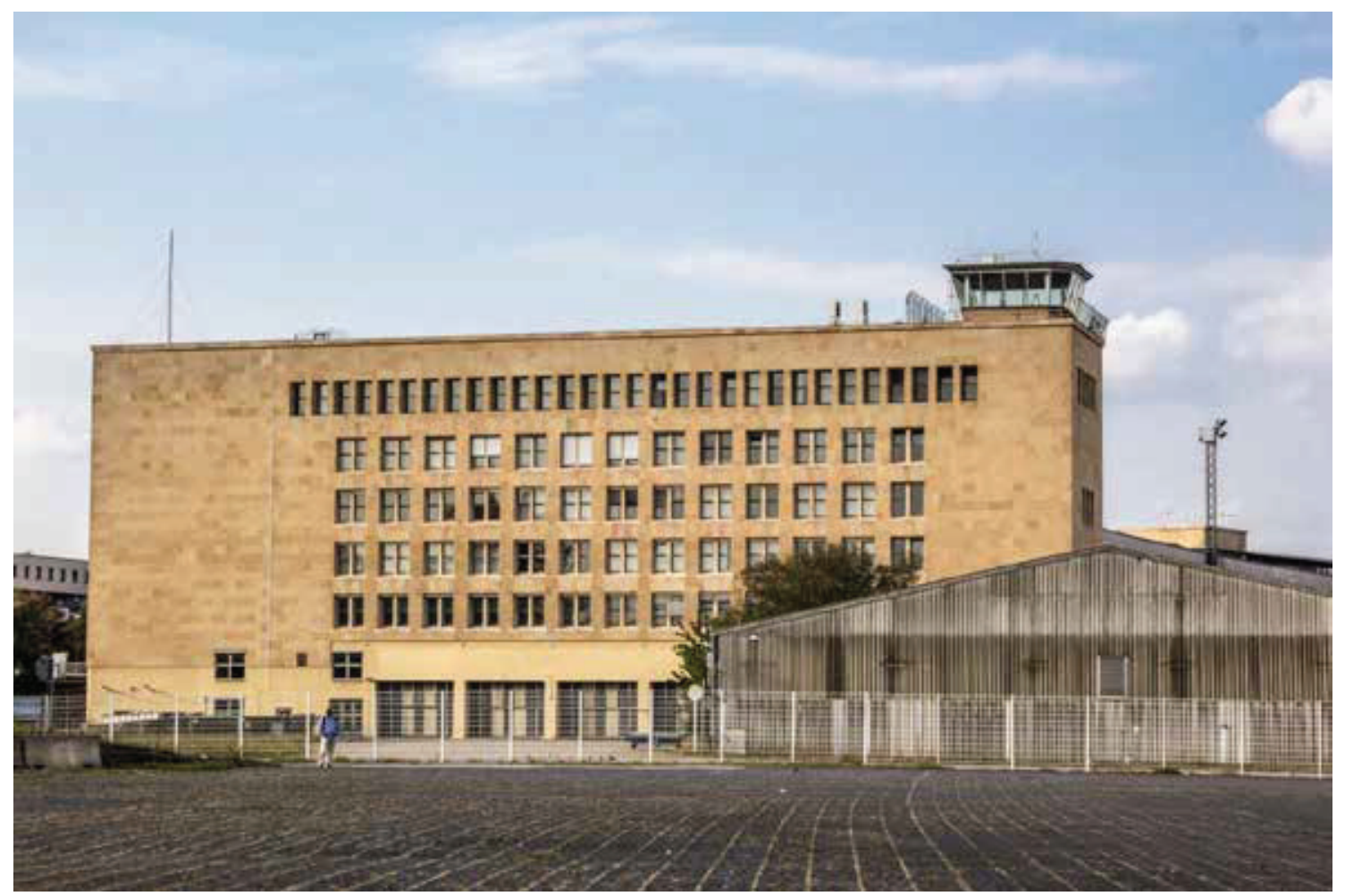

Fiquei animado com a ideia, pois havia entendido que os refugiados ali estariam dispostos a interagir e achei que o trabalho seria possível. No dia seguinte fui ao local, no horário indicado, minha amiga Nicole foi comigo, ela também se interessou pela ideia de ajudar e interagir com refugiados. Procuramos o local por muito tempo, o endereço informado não tinha nenhum "café" e depois de algumas horas procurando, descobrimos que o café era feito em uma outra área do aeroporto que foi destinado a esses encontros.

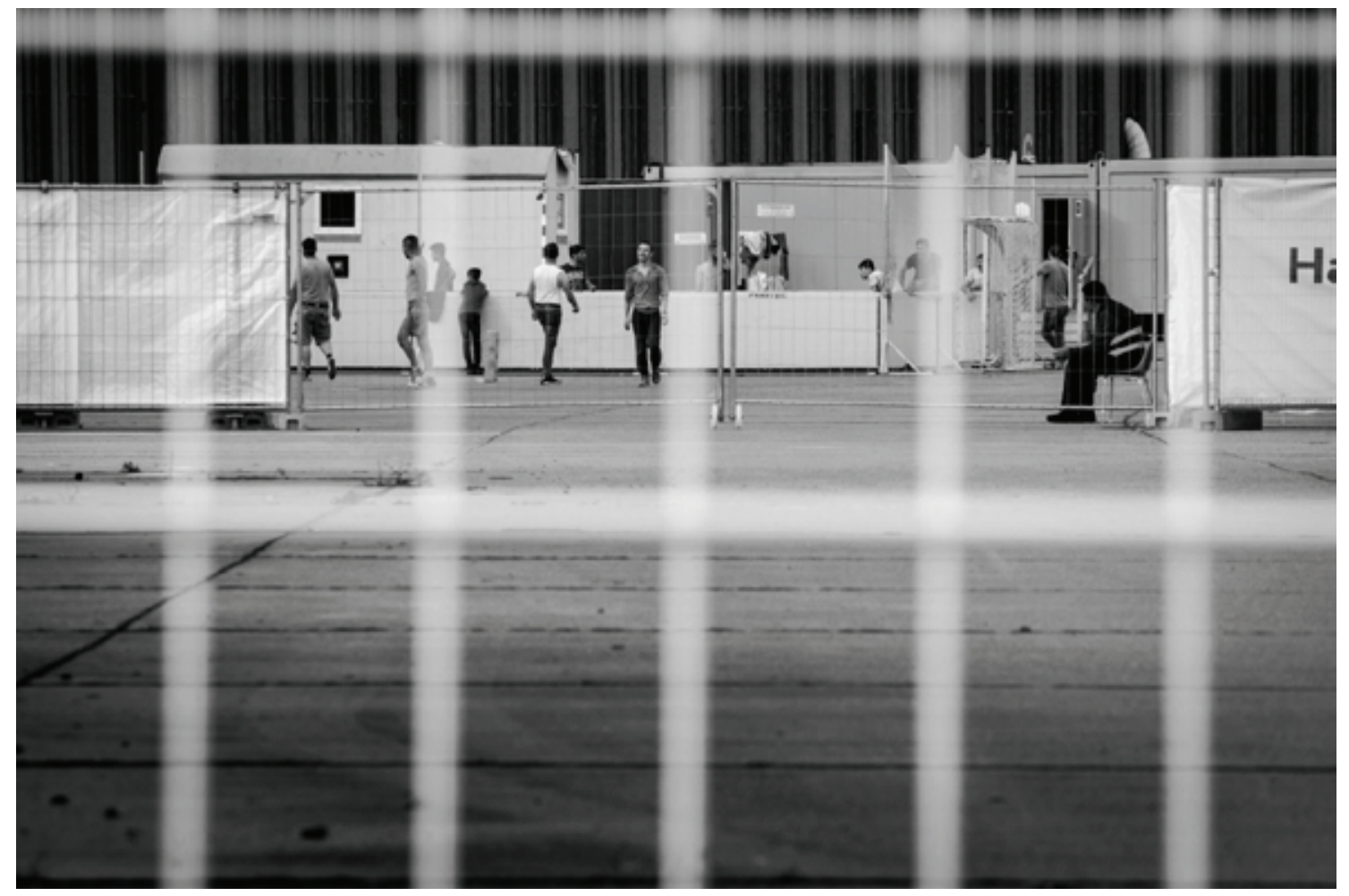


0 antigo aeroporto de Tempelhof é enorme, entramos por uma entrada do outro lado da entrada principal, até acharmos esse local. Ao chegar no local, esperamos do lado de fora um pouco para ver a movimentação e a área, apesar de ter uma placa escrita "café" não parecia um local muito amigável onde pessoas conversavam e interagiam.

Fiquei por volta de 30 minutos do lado de fora, sentado em uma mesa improvisada e observando a movimentação. Muitas crianças estavam brincando ali, crianças cuidando de outras crianças, algumas pareciam estar sozinhas. Resolvi então entrar no local e o que vi não foi um café amigável. Dentro do local, onde eram vendidos refrigerantes, snacks, entre outras coisas, tinha uma sala, na porta dessa sala duas pessoas brigavam com algumas mulheres, era uma sala de "doações" e as pessoas tinham senhas para entrar, mas alguma confusão aconteceu e cerca de oito mulheres brigavam com os homens que cuidavam da entrada.

Ao olhar em volta, vi muitas outras pessoas, na maioria mulheres, que não estavam ali para um café amistoso. Estavam com olhares longe, pareciam que não tinham um outro lugar para estar. Outras pessoas entraram, se juntaram as outras mulheres que brigavam, o clima no local foi ficando cada vez mais tenso e conturbado, algumas pessoas olhavam para mim e para a minha amiga, como se perguntassem o que estávamos fazendo ali. 0 caos aumentou, as mulheres aos gritos umas com as outras iam pegando algumas crianças e iam embora, crianças pegavam crianças menores e iam saindo também, por um momento vi minha vista escurecer, o ar faltar e sai do local antes que eu caísse desmaiado.

O stress no local era tão grande, que minha amiga percebeu o quanto fiquei envolvido e decidimos dar um tempo com as ideias, saímos para tomar uma cerveja no parque. Fiquei pensando naquela cena, mesmo que eu estivesse com minha câmera na mão, me senti completamente impossibilitado de fotografar aquela situação. Pela primeira vez me deparei com o que muitos fotógrafos já devem ter se deparado, sobre a ética na fotografia.

No dia seguinte voltei ao Tempelhof, não no mesmo local onde era feito o "café", fiquei andando ao redor, fiz algumas fotos do prédio e tentei não fazer nenhum contato com a intenção de fotografar ou falar sobre o projeto. Fiquei observando as pessoas entrando e saindo, crianças brincando, algumas mulheres tomando chá e jovens conversando e rindo numa roda de amigos e em alguns momentos tive uma sensação de que aquelas pessoas estavam apenas tento uma vida normal, apreciando um fim de tarde na companhia dos amigos ou vendo seus filhos brincar.

Uma bola bateu em mim, me viro para pegá-la e devolvê-la a uma criança que vinha na minha direção. Ela estava sorridente e seu pai logo atrás, uma cena linda para uma bela foto. Pensei se tirava minha câmera da mochila correndo e tentava registrar aquele momento com uma linda luz, correndo o risco de intimidar essa criança e seu pai e arrumar talvez um problema ou apenas deixasse ela se aproximar para pegar a bola com seu sorriso. Fiquei com a segunda opção. Eu empurrei a bola para ela, que sorriu, jogou para mim novamente, 
olhei para o seu pai logo atrás, que sorriu para mim e fez um sinal de joia. A menina pegou sua bola, sorrimos e ela foi embora. Valeu a pena ter ficado com a segunda opção.

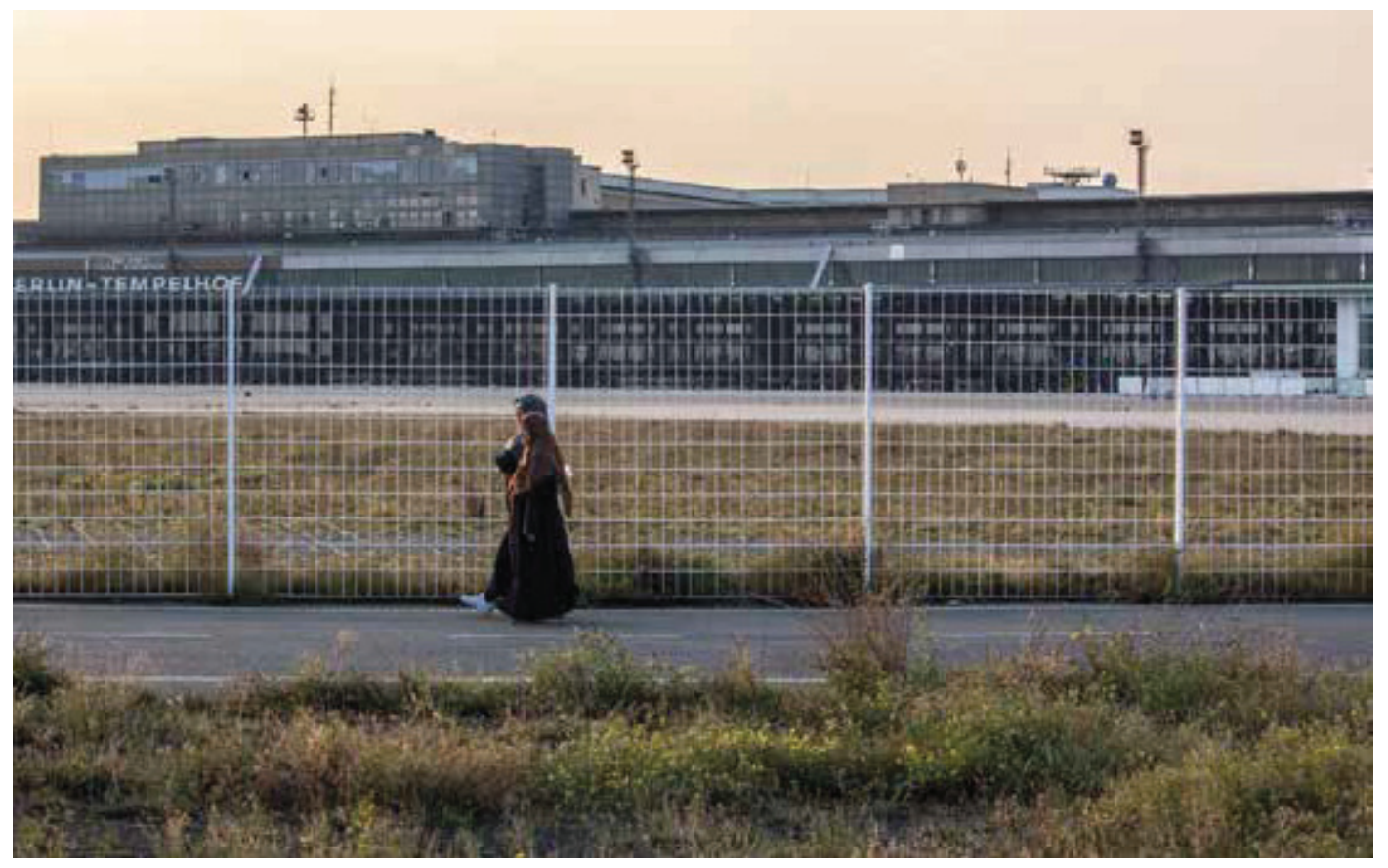

Fiquei mais um tempo no local, observando a movimentação, tentando desvendar os olhares de pessoas que iam e vinham muitas com carrinhos de bebê que serviam para carregar muitas outras coisas além de crianças. Fiquei pensando se conseguiria fazer o trabalho como eu tinha imaginado, mas parecia que estava cada vez mais difícil.

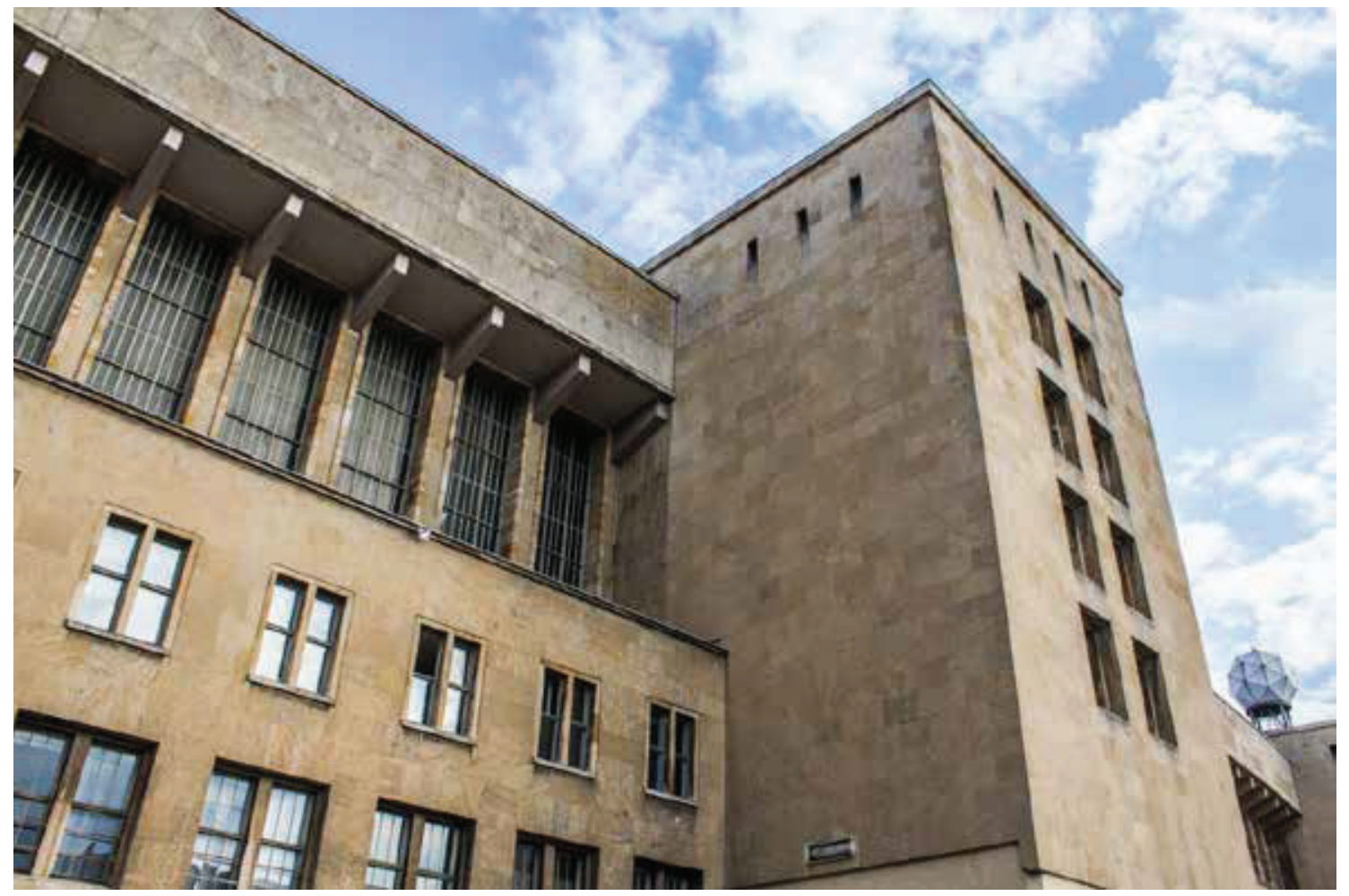


Quando comecei a pensar nesse trabalho, fiz contato com uma pessoa que trabalhava diretamente com refugiados, ela me passou o contato de um deles que pelo que entendi, fazia filmes e que poderia me ajudar. Mandei mensagem pelo número que ela me passou, tentei ligar sem sucesso e depois de alguns dias, ele me respondeu, seu nome é Juma. Trocamos alguns e-mails, tentamos combinar um horário para ele conseguir me atender, pois ele estava com algum problema no seu telefone e achei que ele seria a pessoa ideal para ajudar me aproximar dos refugiados. Mas não conseguia contato com ele.

Durante alguns dias continuei procurando lugares e pessoas que pudessem dar forma ao meu trabalho, mas sem muito sucesso. Os dias passaram e apesar de ter dias ótimos em Berlim, uma cidade tão cheia de coisas para conhecer, estava decepcionado com meu trabalho que parecia não sair do lugar. Faltavam dois dias para o fim da minha estadia em Berlim, quando finalmente, Juma me liga, e conseguimos combinar o dia seguinte para nos encontrarmos em um café, e conversarmos pessoalmente sobre o assunto.

No dia seguinte, encontrei Juma em uma estação de metrô, ele muito simpático estava me esperando. Fomos a um café e ele me contou um pouco sobre a sua história, suas ideias e como poderia me ajudar a ir em outro campo de refugiados, um pouco mais distante que o do aeroporto de TEmpelhof, onde ele tinha ficado por um tempo e que tinha conhecidos lá.

Então fomos ao campo que se chama Tamaja Paulsternstraße um pouco mais afastado do centro. 0 campo foi feito em um galpão atrás de um supermercado, sua entrada fica próxima ao estacionamento

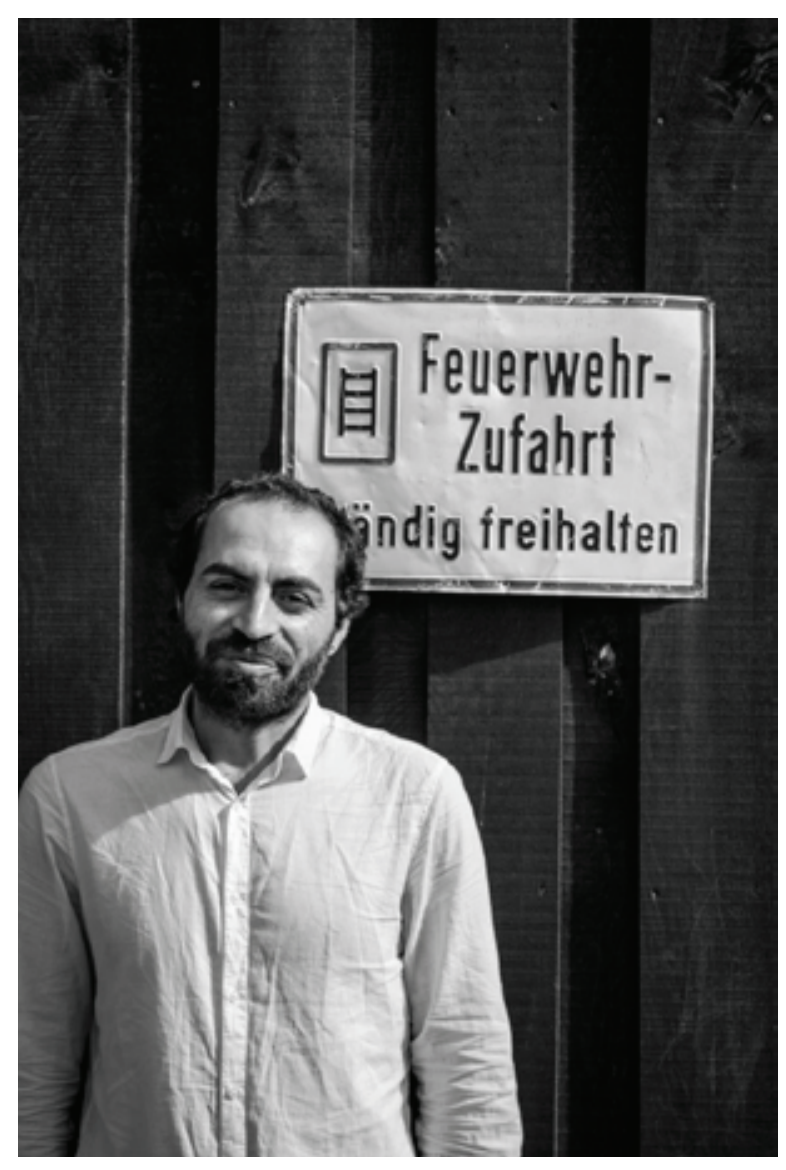
dos carros e logo ao chegar vi algumas crianças brincando por ali, e assim como no campo de Tempelhof, muitas pessoas com carrinhos de bebês que servem para carregar muitas coisas além de crianças.

Logo que cheguei, reparei em uma mulher obesa numa cadeira de rodas. Seu olhar estava distante demonstrava um sentimento muito agoniante, como se ela não tivesse esperança e aguardava a hora de sua morte. Enquanto Juma conversava na entrada do campo para autorizar a minha entrada, fiquei observando-a, imaginando como ela chegara 


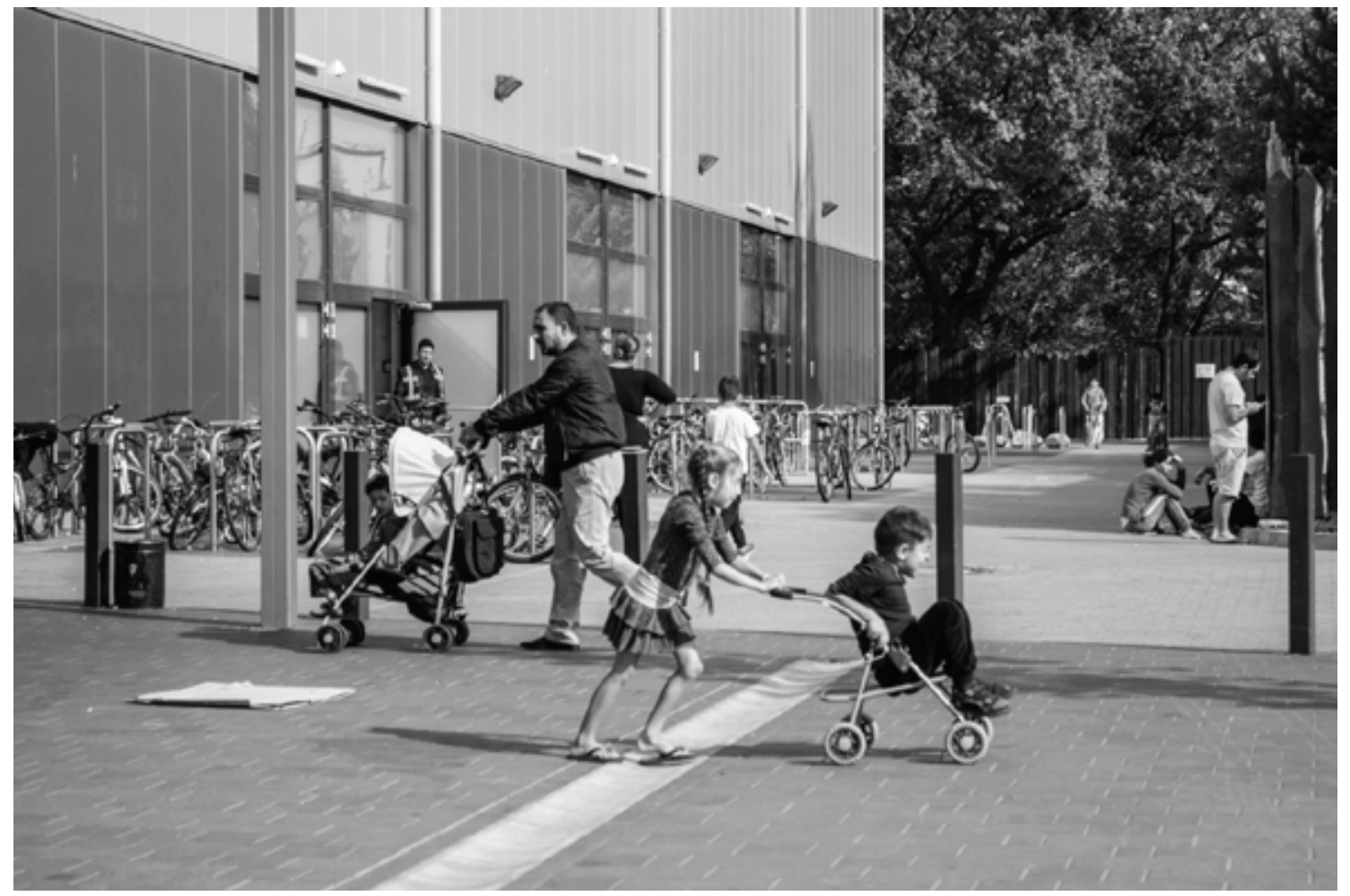

ali. Qual seria a sua história. 0 que ela já teria passado para conseguir estar ali e qual seria sua expectativa sobre o futuro.

Então, Juma retornou dizendo que poderíamos entrar. $\mathrm{Na}$ entrada deixei minhas coisas, não pude entrar com câmera, mas iria falar com a diretora do local para saber se seria possível o registro interno. Juma cumprimentou um amigo que estava trabalhando na distribuição de alimentos e que nos convidou a participar da refeição que seria servida. Ao chegar à sala da diretora, muito simpática, nos convida a sentar e comer um pedaço de bolo que estava sendo servido, pois era aniversário de algum funcionário. A diretora escuta simpaticamente minha intenção de fotografar o lugar, mas nos diz que não seria possível fazer fotos internas, entretanto, caso eu encontrasse alguém que quisesse participar, não teria problemas para fotografar do lado de fora.

Juma foi trás de algumas pessoas que conhecia o local, eu fiquei aguardando em uma mesa, observando o lugar. 0 espaço grande, Juma disse que ali funcionava uma academia. Observo uma prateleira, com muitas tomadas e extensões, com muitos celulares carregando, de vez em quando alguém parava ali, olhava o celular e deixava-o carregando novamente. Ouvi dizer que os smartfones foram extremamente importantes para esses refugiados, através deles eles conseguiam se comunicar com outros que percorriam o caminho e trocavam informações sobre qual caminho seria mais fácil para chegar ao seu destino.

Um garoto com cerca de quatro anos se aproximou de mim e ficou próximo de onde eu estava brincando com um pequeno carrinho. Ele sorria para mim, como se quisesse interagir, mas voltava a se concentrar na sua brincadeira. Outras crianças estavam 


\section{relato de campo}

brincando por ali também, reparo em um garoto maior que os demais, com cerca de oito anos também brincando, porém a sua brincadeira não parecia tão ingênua quanto a das crianças menores. Ele se aproxima do menino com seu carrinho, toma o carrinho da mão dele, que protesta. 0 garoto maior dá um forte tapa em sua cabeça e fala algo com voz dura para o garoto menor. Ele pega seu carrinho e sai saltitante e sorridente como se tivesse poder naquele lugar. 0 garoto que fica sem seu carrinho chora angustiadamente. Outras pessoas adultas nem o notam e ele sai caminhando chorando copiosamente, sem ninguém para ampará-lo.

Tive vontade de correr e abraçar aquele garoto, de ir atrás do garoto maior, tomar o carrinho dele e dar uma lição para que não abuse dos menores, mas fico apenas vendo o garoto menor se distanciando e o outro garoto fazendo a mesma coisa com outras crianças. Fiquei pensando se aquele garoto podia ter alguma referência violenta de onde viveu ou se ele é apenas igual ao garoto valentão que tinha na minha escola.

Juma voltou com duas pessoas, conversando alegremente em Árabe. Juma os apresenta para mim, Jafar Al Ali e Rami. Ambos Sírios me cumprimentam e vamos do lado de fora acompanha-los para um cigarro. Sentamo-nos em uma mesa do lado de fora, enquanto Juma explica quem sou e o que tenho intenção de fazer, Jafar enrola um cigarro bem grosso e me oferece junto de um copo d'água. Juma me diz que seria rude da minha parte não aceitar aquele cigarro e aquela água, que ele com dificuldade tirou de uma garrafa plástica de refrigerante congelada. Ele rasga o plástico da garrafa e com a mão vai tirando pedaços menores de gelo. Fico receoso de beber aquela agua, mas claro que não recuso.

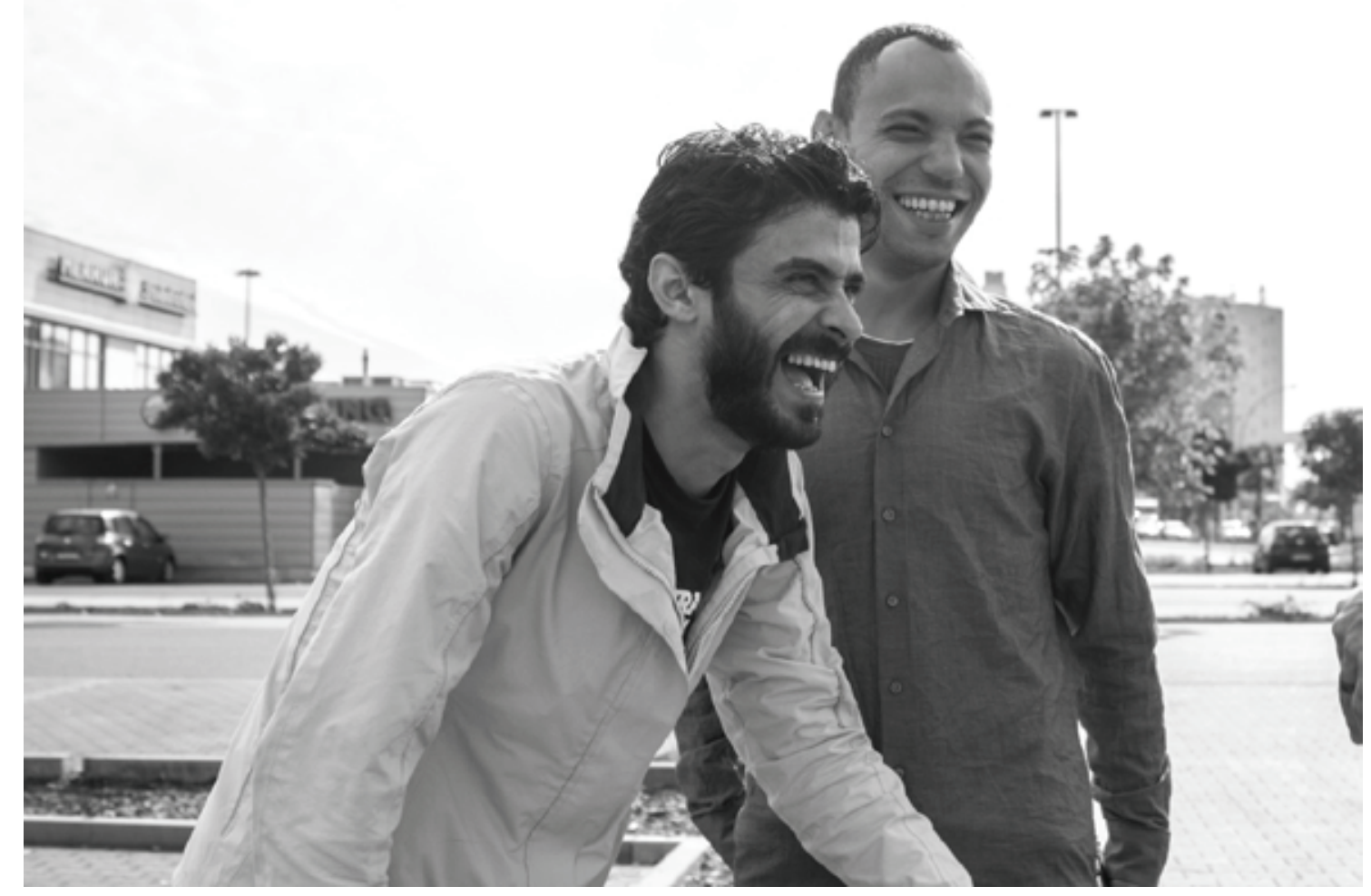


Juma explica para eles que eu gostaria de ouvir um pouco de suas histórias e fotografá-los por ali. Jafar se mostra interessado e sem constrangimento, enquanto Rami parece não saber se gosta da ideia. Al Ali logo começa a falar de sua história em árabe, enquanto Juma traduz para mim em inglês, pois ambos só falam Árabes.

Al Ali começa falando sobre sua cidade, Deir Ezzour Leste da Síria. Ele me disse que a sua cidade está sobre controle do grupo terrorista ISIS e que ele foi embora da cidade para não morrer. Ele tira o celular do bolso e começa a me mostrar fotos de familiares

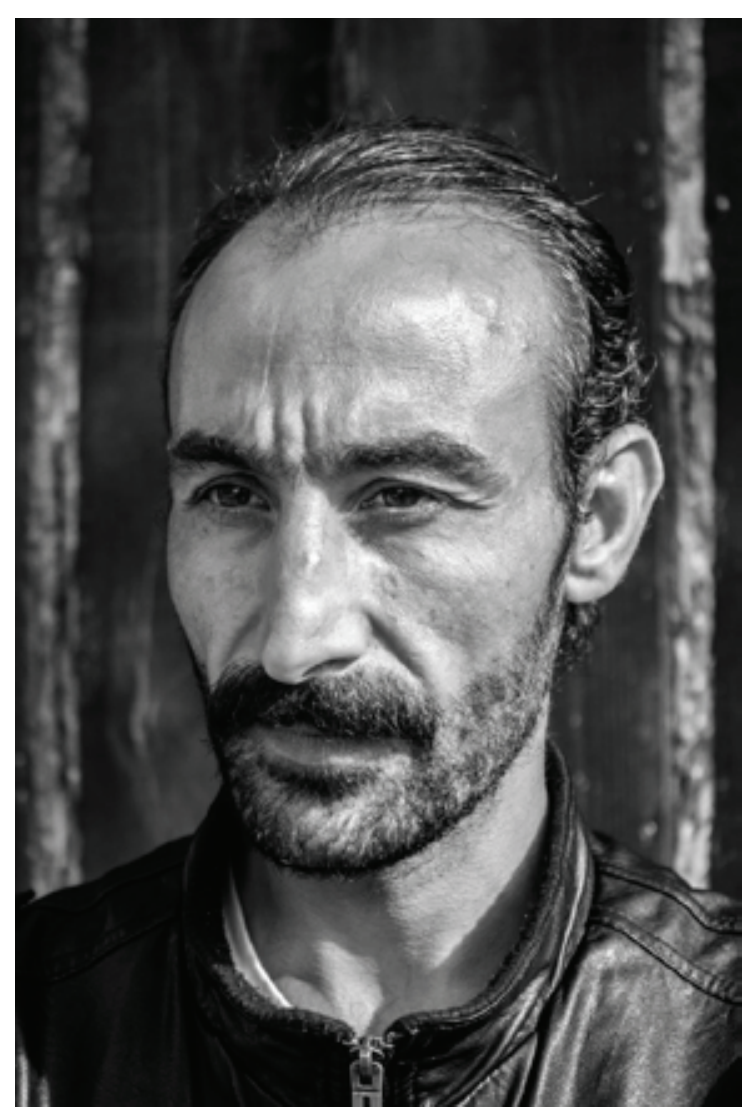
e amigos que foram mortos por esse grupo, das maneiras mais brutais e sem motivos aparentes. Ele me fala de um familiar que cortaram a sua cabeça, que ele estafa fumando um cigarro em local público e o grupo deixou sua cabeça exposta na cidade para intimidar outras pessoas que não obedecem às regras.

$\mathrm{Al}$ ali me disse que sua esposa e filhos continuam na cidade e que já está em Berlim há quase um ano a procura de residência e assim trazê-los para junto dele. Durante a conversa, Rami faz algumas piadas e mesmo quando se descontraia, seu olhar continuava sério e um tanto quanto distante. Eles começam alguma discussão sobre política, e mesmo Juma tentando me explicar as suas opiniões, pouco consigo compreender.

Então Al Ali se levanta e pergunta onde quero fotografá-lo. Rapidamente pego minha câmera e caminhamos um pouco distante para que outros não nos vissem fotografando. Al Ali se porta diante de mim, como se gostasse daquilo ou que talvez fosse importante para ele. Ele cruza os braços, faço alguns cliques, aproveito para fotografar Juma também. Enquanto voltamos para mesa onde estávamos, Al ali prepara um novo cigarro, e me entrega sem questionar se eu gostaria de fumar.

Enquanto nos aproximamos da mesa, uma viatura de polícia se aproxima, Rami chama por juma que pede para eu aguardar com $\mathrm{Al}$ ali e ele entra correndo com Rami, não entendo muito bem o que acontecia, mas parecia sério. Fico sentado com Al Ali, cada um fuma o seu cigarro, mas nada conseguimos conversar, pois não falamos a mesma língua. Após alguns minutos, Juma e Remi voltam com outra pessoa, com cara de sono eles se aproximam e Juma me apresenta à Khalil. Juma me explica que Khalil é do Cairo no Egito e ele não tem permissão para estar na Alemanha, que essas visitas dos policiais são para 
buscar pessoas ilegais dentro dos campos. Eles correram para esconder Khalil que estava dormindo. Aquilo já era uma rotina na vida dele, toda semana ele se esconde para não ser deportado.

Khalil também aceita o convite de conversar e ser fotografado, mesmo com certa timidez, ali mesmo faço algumas fotos dele. Ele me conta que no Egito trabalhava como alfaiate, que saiu de lá em busca de uma vida melhor na Europa. Enquanto conversávamos, algumas crianças se aproximam da mesa ao lado, algumas pessoas passam por nós e quando veem a câmera em minhas mãos cobrem o rosto.

As crianças comem um lanche e olham com curiosidade para a câmera. Seu pai ali

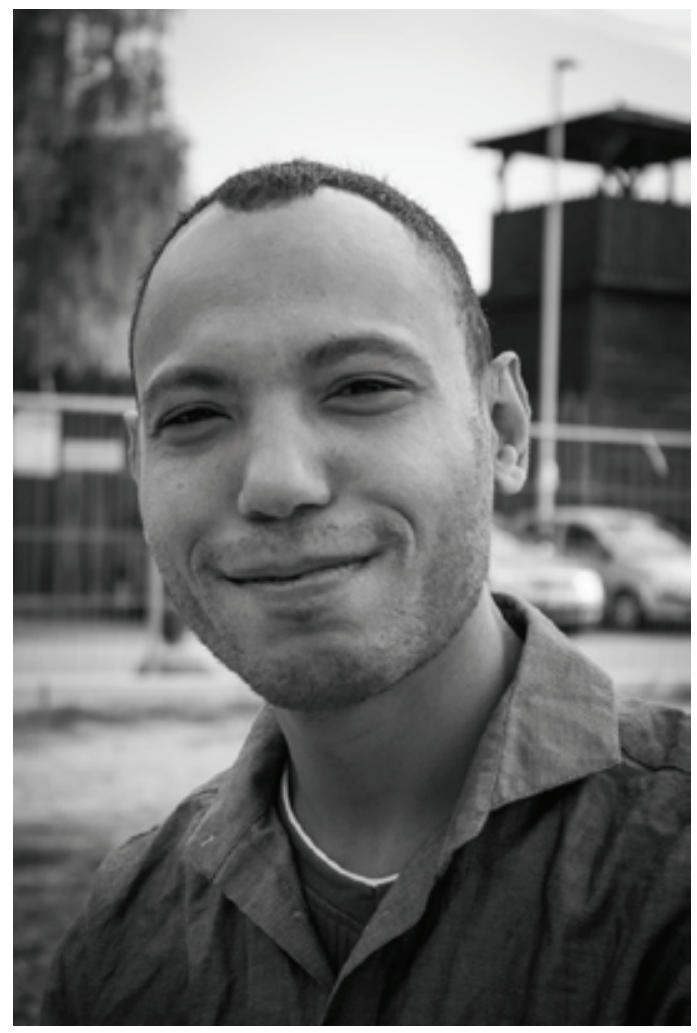
perto se aproxima e conversa alegremente com os outros. Pergunto a Juma se ele deixaria tirar algumas fotos das crianças e ele sorridente diz que sim e chama as crianças. Ele fala para elas que sou do Brasil e uma das garotas corre para buscar uma bola de futebol, volta me dizendo que é fã de futebol e joga muito bem. Seu pai confirma.

Eles são de Damasco, saíram da Síria há um ano e após seis meses na Suécia, estão na Alemanha já com visto. Duas meninas e um garoto se aproximam alegremente para posar para as fotos, seu Pai também, porém a mãe, de longe, tapa o rosto cada vez que levanto a câmera. Tiramos algumas fotos, brincamos, damos risadas e uma Van se aproxima para busca-los para ir à escola. Juma diz que as crianças já falam muito bem o alemão e que estão bem ambientadas com a cidade.

Juma apressa Rami, que estava de alguma forma tentando se esquivar para não tirar fotos. Rami é de Aleppo, era taxista e também fugiu por causa da violência. Tiramos algumas fotos, ele não fala muito

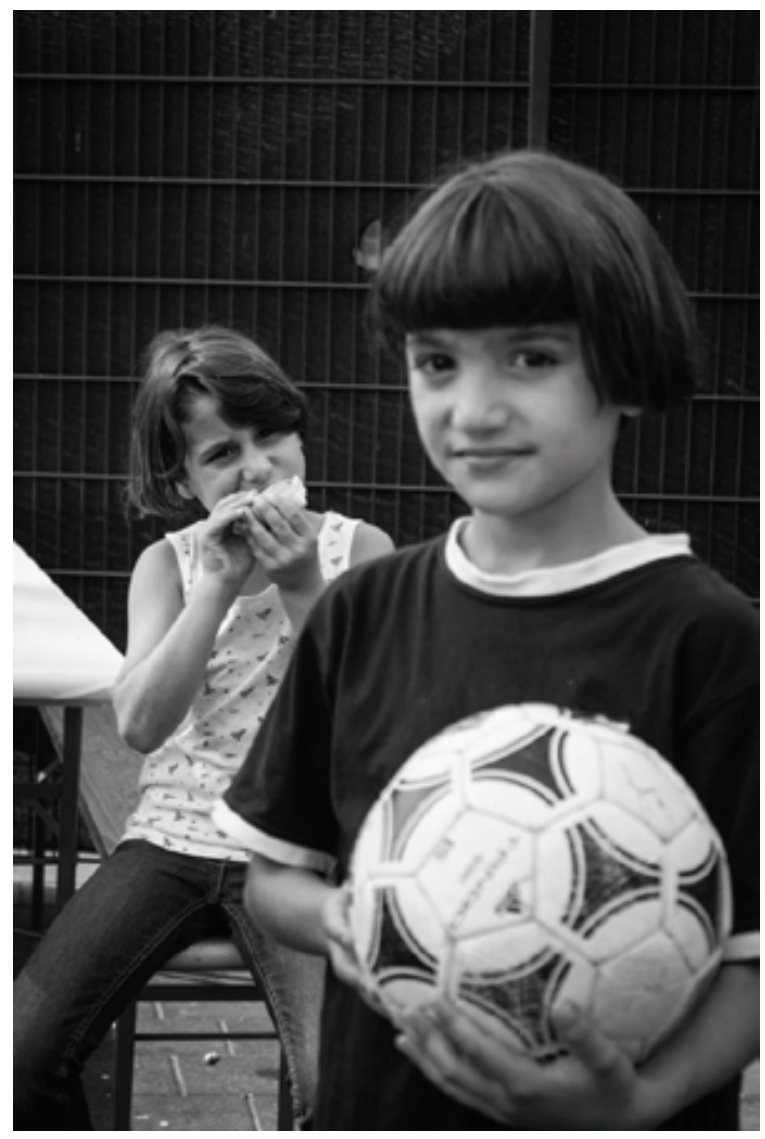



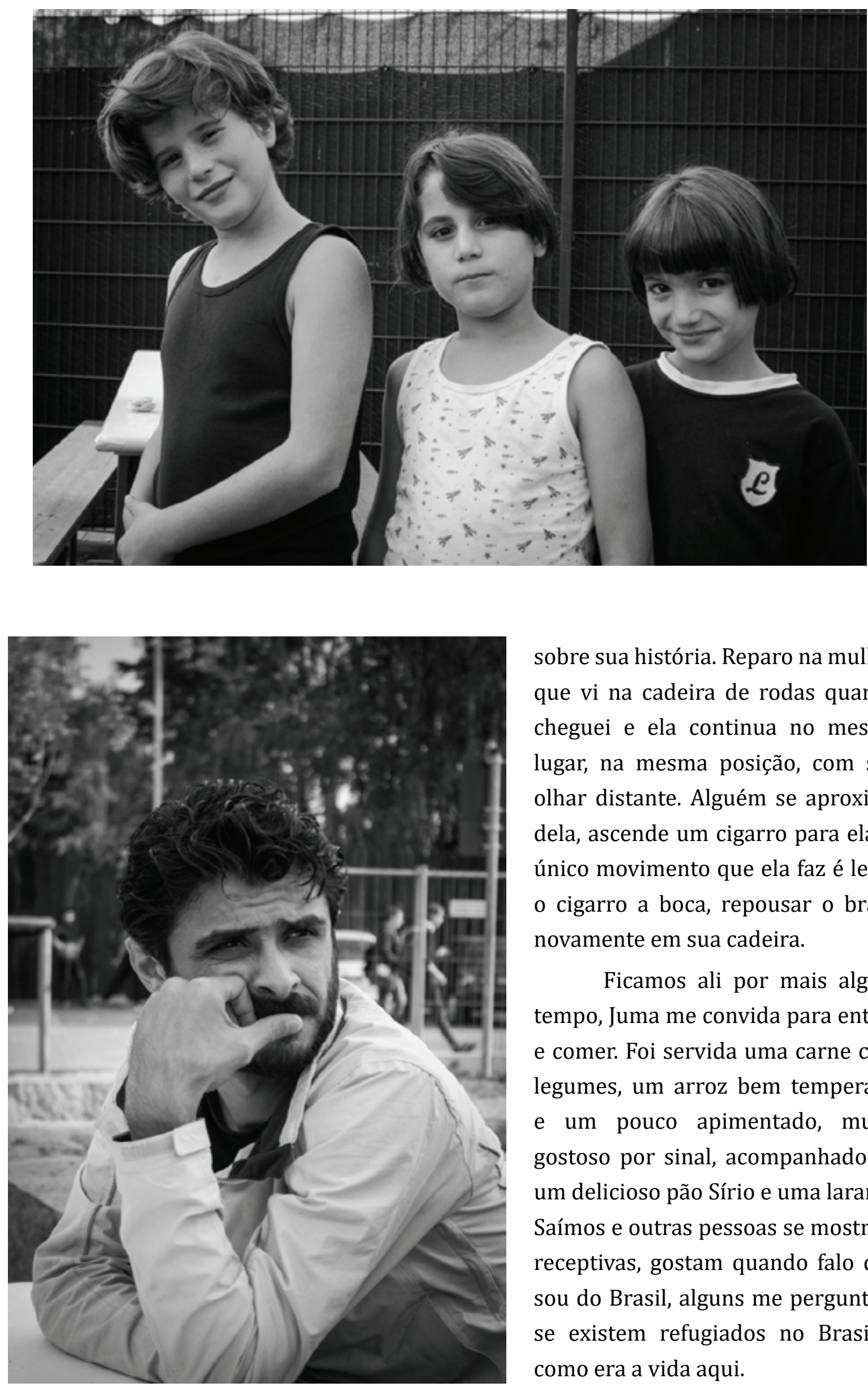

sobre sua história. Reparo na mulher que vi na cadeira de rodas quando cheguei e ela continua no mesmo lugar, na mesma posição, com seu olhar distante. Alguém se aproxima dela, ascende um cigarro para ela, o único movimento que ela faz é levar o cigarro a boca, repousar o braço novamente em sua cadeira.

Ficamos ali por mais algum tempo, Juma me convida para entrar e comer. Foi servida uma carne com legumes, um arroz bem temperado e um pouco apimentado, muito gostoso por sinal, acompanhado de um delicioso pão Sírio e uma laranja. Saímos e outras pessoas se mostram receptivas, gostam quando falo que sou do Brasil, alguns me perguntam se existem refugiados no Brasil e como era a vida aqui. 
relato de campo

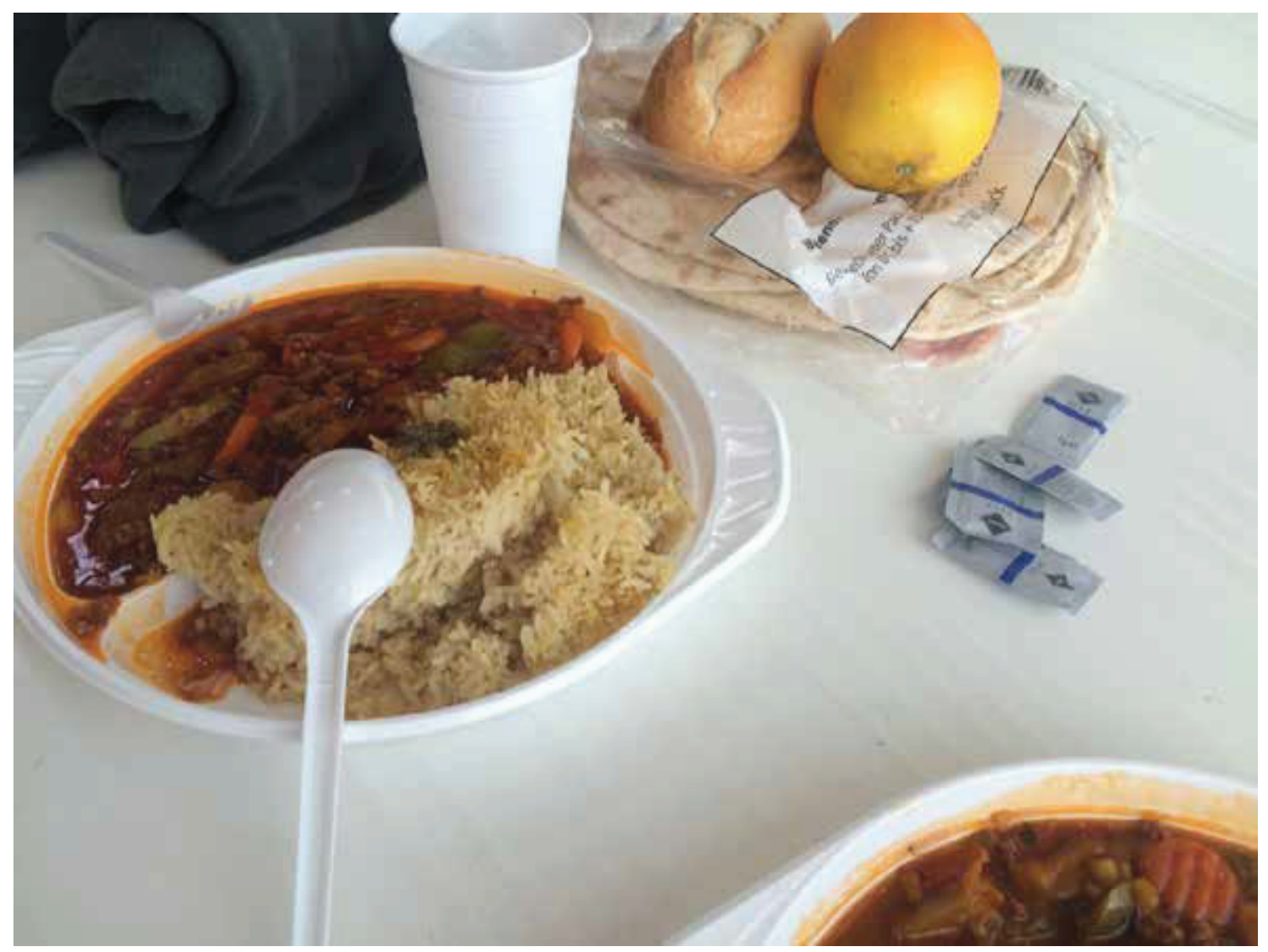

Juma me diz que precisa ir embora e decido ir com ele. Dois rapazes vêm até mim e dizem que, caso eu queira voltar ali, eles me ajudariam a conversar com outras pessoas e fazer mais fotos. Super simpáticos, peguei os telefones e digo que faria o possível para voltar ali, mas infelizmente teria apenas mais um dia em Berlim, que tinha reservado para passear com minha amiga de longa data no meu último dia na cidade.

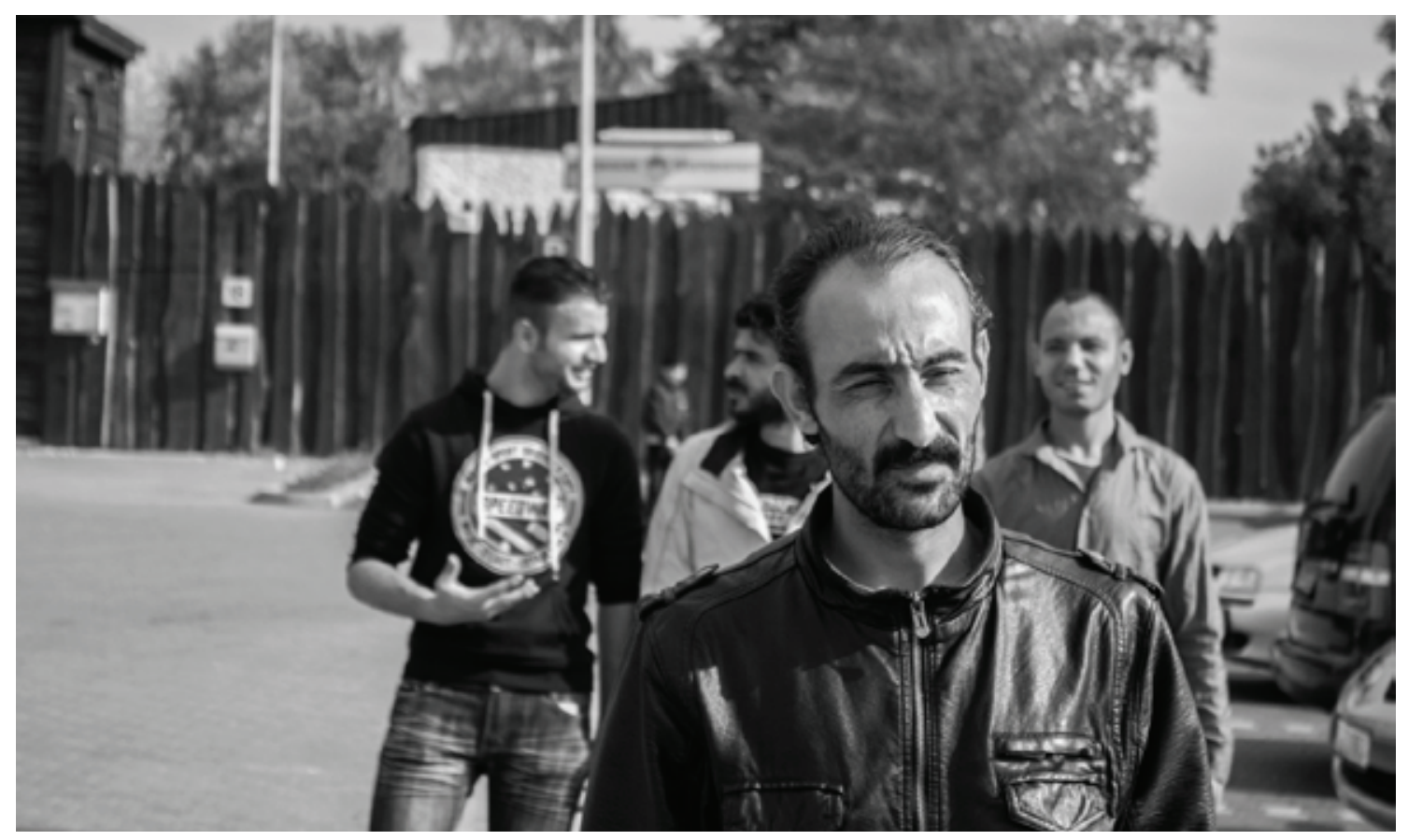




\section{relato de campo}

Fui embora e percebi que a mulher na cadeira de rodas agora estava em outro lugar, mas ainda sim sozinha com seu olhar distante e um cigarro aceso. Voltei com Juma para o metrô, onde nos despedimos e deixamos em aberto uma possível cerveja para mais tarde e promessas de troca de informações.

Aproveitei meu último dia em Berlim, andando pela cidade de bicicleta com minha amiga, e um pouco aliviado por ter conseguido ter um curto acesso à vida desses refugiados. Percebi que o trabalho que eu tinha intenção de fazer pode ser feito, mas com mais tempo na cidade, com visitas diárias, algum serviço voluntário para ganhar a confiança dessas pessoas. Percebi que apesar de serem livres nesses campos para entrarem e sair quando quiser, o clima é de prisão. Que muitos estão ali de mão atadas aguardando uma solução que não sabem de onde vem, para conseguirem seguir suas vidas. Percebi que nós como sociedade ainda não nos conscientizamos do real problema dessas pessoas, do desespero que é não ter mais sua terra natal como lar, e também apesar dos esforços de muitas pessoas, ainda não são tão aceitos naquela cidade. Muitas placas ao redor da cidade protestam contra a presença deles na cidade, como se eles estivessem más intenções ou fossem oportunistas.

Em uma conversa com Juma, ele acredita que essas pessoas conseguirão permanecer na Alemanha. Que irão encontrar trabalho e aos poucos irão se misturando construindo a nova cara da população de Berlim. Basta saber se eles irão mesmo conseguir fazer parte da população e desfrutar o excelente estado de bem-estar social alemão.

Voltei para o Brasil com a sensação de dever "quase" cumprido, mas também como uma pessoa mais humana, um fotógrafo com um pouco mais de experiência e com mais interesse pela fotografia, como ela é importante não só pelo registro de uma época ou situação, mas como objeto de denúncia e conscientização, isso me dá forças para seguir com ela.

Texto recebido em 17 de Dezembro de 2016 e Aprovado em 24 de Março de 2017

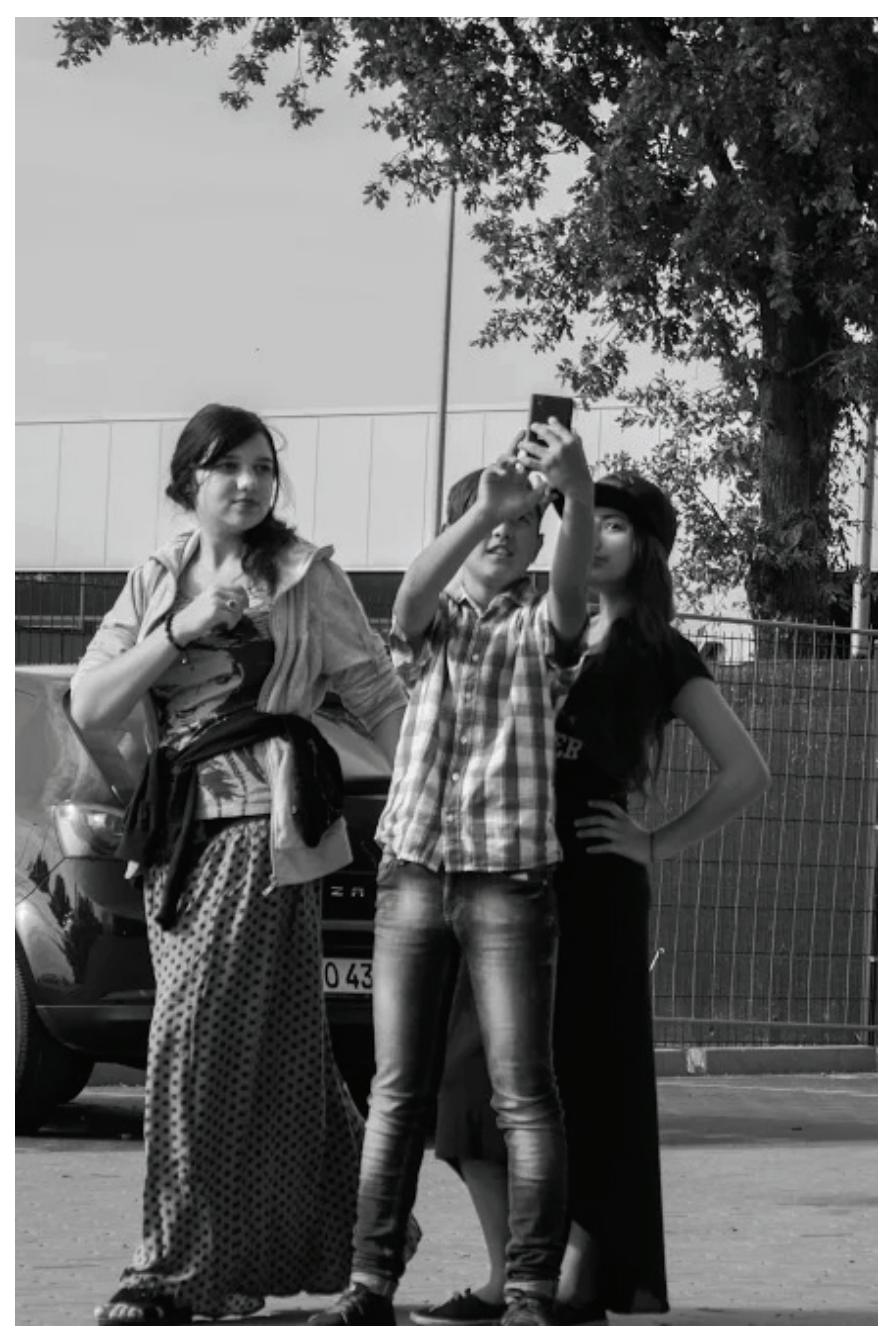

